DOI: https://doi.org/10.47405/mjssh.v6i5.775

\begin{tabular}{|c|c|}
\hline 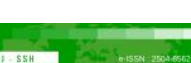 & Malaysian Journal of Social Sciences and Humanities (MJSSH) \\
\hline $\begin{array}{l}\text { Malaysian Journal of } \\
\text { Social sciences and }\end{array}$ & Volume 6, Issue 5, May 2021 \\
\hline (MJ-SSH) & e-ISSN : 2504-8562 \\
\hline & $\begin{array}{l}\text { Journal home page: } \\
\text { www.msocialsciences.com }\end{array}$ \\
\hline
\end{tabular}

\title{
Teacher Readiness to teach Quantum Physics (TRQP): An Instrument for Form Five Physics Teacher in Secondary School
}

\author{
Stephanie Sungkim ${ }^{1}$, Laurah Markus ${ }^{1}$, Mohd. Zaki bin Ishak ${ }^{1}$ \\ 1Faculty of Psychology and Education, Universiti Malaysia Sabah (UMS), Malaysia \\ Correspondence: Stephanie Sungkim (stephaniesmkatunas@gmail.com)
}

\begin{abstract}
This study aims to determine the validity and reliability of Teacher Readiness to teach Quantum Physics (TRQP) instrument using Rasch Measurement Model. The TRQP was developed to measure the level of teacher readiness to teach quantum physics in secondary schools. TRQP consisted of 41 items containing three constructs namely: content knowledge, attitudes, and readiness. The research sample consisted of 30 Form Five Physics teacher from secondary schools in Sabah. The results of the validity analysis found that the polarity of the items through the PTMEA-CORR values showed that all 41 items were $>$ $0.00(+)$. Through item fit analysis, all items were retained because they met the requirements in one of the MNSQ, Outfit ZSTD, and PTMEA-CORR outfit ranges. In the Principal Component Analysis (PCA), the Raw Variance Explained by Measures value of $40.6 \%$ and the Unexplained variance value in the first to fifth contrast below $15 \%$ indicates that the instrument has a strong dimensional dimension and has high construct validity. The reliability of Cronbach Alpha (KR20) showed a value of 0.87 (high), item reliability of 0.88 (very good), and person reliability of 0.81 (good) with separation item value of 2.73 (good) and separation person value of 2.04 (good). In conclusion, TRQP has good validity and reliability in measuring the level of teacher readiness to teach quantum physics in terms of content knowledge and attitudes among Form Five Physics teachers in secondary schools.
\end{abstract}

Keywords: validity and reliability, quantum physics, teacher readiness, secondary schools, rasch measurement model

\section{Introduction}

Quantum physics (QP) has been implemented in the secondary school curriculum in several countries years before Malaysia due to its importance in modern technology applications. Since QP will be implement be taught to our secondary school students in 2021 based on the revised new curriculum $(K S S M)$. Due to this newly revised curriculum, the training for teachers is not yet implemented thoroughly. Based on a study regarding teacher readiness, the main elements of teacher readiness are knowledge, attitudes, and interest (Park et al., 2016). The study by Fan et.al. (2019) indicates content knowledge and attitudes as part of the teacher readiness component. Therefore, the teacher needs to enhance their content knowledge to be ready to teach QP by providing the teacher with training. As supported by Balta (2018), intense QP training for teachers should follow up so that teachers are not felt on their own and unfair as a result of the implementation of this new revamp curriculum. 
The implementation of QP in the physics curriculum requires teachers to have a good understanding of the conceptual meaning of QP. Teachers are not ready to teach QP because they do not have strong content knowledge of QP topics (Balta, 2018). To achieve the expected competencies, the teachers should have good previous content knowledge before teaching QP. Teachers should be positive about the topic to be implemented to help students understand and give positive feedback to students on the topic studied (González-Gómez et al., 2019; Ulug et al., 2011). The new revamp curriculum indicates there is a need to measure the level of teacher readiness among the teachers to what extend the knowledge and attitude influence the teacher readiness to teachQP. This is to make sure the teachers' needs are met to enhance student performance and to enhance the students' performance.

Nevertheless, previous studies on QP research in the past have primarily been conducted at the higher level of education. Additionally, previous research has revealed findings regarding university students' knowledge of quantum physics (Calýskan, Selçuk, \& Erol, 2009). Similarly, studies on the level of readiness of many teachers in general for science and mathematics subjects are not specific to secondary school teaching of quantum physics. Thus, the focus of this study is to develop an instrument to study to what extent the level of readiness of teachers to teach quantum physics in secondary schools in terms of content knowledge and attitudes.

\section{Literature Review}

\section{Quantum Physics in Secondary Schools Curriculum}

Quantum physics (QP) has been in the undergraduate curriculum for so many years before it is introduced to the secondary school curriculum. QP must be included in the school curriculum since QP is a fundamental theory of physics (Michelini \& Stefanel, 2010). Australia, France, and Norway have already put QP in their physics curriculum for students' age range of 17 to 19 years old to learn this particular topic (Stadermann, Van Den Berg, \& Goedhart, 2019). Meanwhile, the Dutch secondary school had introduced QP to its curriculum in 2016 (Krijtenburg-Lewrissa, 2020). QP has become part of the secondary school curriculum hence the school physics curriculum is reformed because of its theoretical and practical importance (Krijtenburg-Lewerissa, Pol, Brinkman, \& van Joolingen, 2019). Despite the crucial role of QP in secondary school's curriculum yet QP is a challenge not only to the student but also to the teachers (Michelini, Santi, \& Stefanel, 2014). The challenge is basically about the foundation understanding of QP is very different from classical physics. For example, one of the differences is related to the mathematical aspects which are more complex than the calculations involved in classical physics (Pospiech, 2019). On the other hand, in Stadermann and Goedhart (2020) study state that QP is a subject that fascinates students. For example, students state that the topic is more mysterious than classical physics because there are still unanswered questions. Even though QP is without a doubt one of the most challenging topics in the physics curriculum, but based on the importance discussed, it is proved that many scholars agree QP should be in the secondary school curriculum.

Teachers encounter challenges in teaching QP is the majority of them do not have a QP background in their undergraduate studies (Lautesse, Vila Valls, Ferlin, Héraud, \& Chabot, 2015). This led to less confidence among teachers to teach this topic when they tend to depend on textbooks (Cheong \& Song, 2014). Wave and particle is a fundamental concept in QP that presents the wave and particle characteristics which varies with classical physics (Héraud, Lautesse, Ferlin, \& Chabot, 2017). Because of this issue, Bungum et al. (2015) study found that teachers need a lot of easily accessible resources related to QP. In order for them to explain the challenging topics in QP such as the wave-particle duality of photons and Heisenberg's uncertainty principle (Cheong \& Song, 2014). There are issues due to the difficulty of conducting experiments regarding QP in the secondary school laboratory. However, a study by Daniela et.al, (2015) found that there is a certain topic that can be done with the low cost such as the experiment of Plank constant. They also found that some of the QP-related experiments can be done in secondary school at a low price, simple, and able to help students understand some QP phenomena. Although learning and teaching challenges for QP topics are diverse, previous studies have suggested several strategies for addressing these. 
Based on previous research, there are many suggestions by experts on the topics in QP that should be added to the physics curriculum for secondary school. Table 1 shows the analysis of secondary school QP curricula of 15 different countries by Stadermann et al. (2019), among the 17 topics of QP most of the countries have the same similarities in choices of QP topics which they implemented in their physics curriculum in upper secondary school. Based on the analysis in Table 1, it gives an insight that the 7 topics stated are crucial to be learned by secondary students. It turned out that the QP topics that have been added to our physics curriculum, are relevant for being introduced to students in secondary schools. This also gives an insight that teachers need to have the adequate content knowledge to teach students and subsequently be ready to teach QP since the topics are challenging.

Table 1: Frequency of QP Topics in Secondary Schools Curriculum for 15 Countries

\begin{tabular}{lc}
\hline \multicolumn{1}{c}{ QP Topics } & Countries/15 \\
\hline Blackbody Radiation & 9 \\
Bohr Atomic Model & 13 \\
Discrete Energy Levels (Line Spectra) & 15 \\
Interactions between Light and Matter & 13 \\
Wave-particle Duality & 15 \\
Matter Waves, Quantitative (de Broglie) & 12 \\
Technical Applications (SEM, LED, Laser) & 13 \\
Heisenberg's Uncertainty Principle & 9 \\
\hline
\end{tabular}

Source : Stadermann et al. (2019)

As for our context, topics that teachers will be teaching in QP by 2021 are shown in Table 2.

Table 2: Topics of Quantum Physics in KSSM

Light Quantum Theory

Photoelectric Effects

Einstein's Photoelectric

Theory

\author{
Ideas of Quantum Theory \\ Quantum Energy \\ Blackbody Radiation \\ Wave-Particle Duality \\ Concept of Photons \\ Plank Constant \\ Problems Related to Energy \\ Photon Power \\ Properties of Photoelectric Effects Using Wave Theory \\ Einstein's Equations \\ Threshold Wavelength \\ Work Function \\ De Broglie Wavelength \\ Photoelectric Current Generation in A Photocell Circuit \\ Photoelectric Effect Applications
}

Source: Bahagian Pembangunan Kurikulum (2018)

\section{Teacher Readiness to Teach Quantum Physics}

Teacher readiness is one of the important elements in teaching and learning processes especially for a new topic and new curriculum introduce. Teacher readiness can be defined as the stage of planning whereby teachers have a positive attitude to transition and a willingness to act in the future for the benefit of the students (Holt \& Vardaman, 2013). As for the context of this study, it refers to a new topic which is QP being introduced in the physics curriculum. In this perspective, teacher readiness depends on the maturity and experience of a teacher (Du \& Chaaban, 2020; Kondakci et al., 2017). Teacher readiness is also defined as the willingness of the teacher to take on responsibilities that cover aspects such as interests, attitudes, knowledge, and skills (Wearmouth et al., 2000). 
In the previous study, the researcher found that one of the factors that influenced teacher readiness is content knowledge. In terms of knowledge, according to Shulman (1987), there are three categories which are: (a) the subject matter content knowledge, (b) the pedagogical content knowledge, and (c) the curriculum knowledge. Besides, content knowledge is also known as the knowledge acquired by teachers in epistemology include facts, concepts, function, and theories as well as teaching their students (Jwaifell, 2019). Based on the study by Ramli and Talib (2017) found that teachers that have a high level of content knowledge, have more capabilities to apply knowledge into daily life phenomenon to simplify the content for their students. These qualities in teachers indicate that the teachers are ready to teach any particular new topic. A questionnaire-based study showed that a high level of content knowledge will lead to a high level of teacher readiness (Poh et al., 2020; Rohaida, 2017). The findings of the study showed that teachers prepared more teaching materials to produce a fun learning environment when they are readily equipped with a high level of content knowledge. Further, by mastering the content knowledge, the teacher able to modify activities that help the student learn (Ramli et al., 2017). However, other than content knowledge, pedagogical content knowledge also one of the factors that influence teacher readiness (Chieng \& Tan, 2019; Mousa, 2016). Concerning research on teacher knowledge, Shulman (1987) also stated there is a weak point concerning content knowledge and introduced pedagogical content knowledge. By implementing pedagogical content knowledge in class, teachers can clarify concepts and procedures from different perspectives before they were able to integrate the content knowledge with pedagogical and curriculum knowledge. It is argued by researchers that pedagogical content knowledge is important for teaching, however pedagogical content knowledge alone cannot be improved if teachers do not have a high level of knowledge at the beginning (Widodo, 2017). Moreover, a study by Kleickmann et al. (2017) found that content knowledge indeed a required prerequisite and a necessity for pedagogical content knowledge development among teachers. The study emphasized that without mastering content knowledge, teachers are not able to deliver the teaching effectively.

Other than content knowledge, according to Ungar (2016), another factor that influences teacher readiness is attitudes. Fishbein and Azjen (1975) refer attitude to as how individuals look at something or someone, either favorably or unfavorably. Attitudes are feelings a person has about something based on their knowledge and belief about the thing they are concerned with (Holt et al., 2007; Nilsson \& van Driel, 2011; Yari et al., 2019). A teacher's attitudes, for teaching QP in this context, refers to the attitudes of physics teacher which involves preparation, expectation, and efforts towards teaching QP within the school context. Teachers that have a positive attitude towards educational reform also have a high level of readiness. The study by Avidov-Ungar and Eshet-Alkalai (2011) found that teachers that have a positive attitude towards teaching new topic also have a high level of readiness. teachers with positive attitudes willing to do more preparation for the teaching process even though it's their first time implement the metaphor approaches in teaching. The teachers in the study also believe they eventually improve their way of teaching using the metaphor approach by willingly learn from expert teachers. Further, teachers with positive attitudes shows higher commitment in teaching the new topic compared to teachers with less positive attitudes where teachers were passionate and relentless with their teaching (Santiago, 2019). This findings is also supported by the study of Mohd Yusof and Ibrahim (2012) which they found that teachers in the study shows positive attitudes towards readiness when they can understand the needs of the curriculum. Once they have the deep understanding towards the curriculum needs, they were able to deliver the teaching effectively to students.

It is no doubt that teacher readiness is one of the important elements in teaching and learning processes especially for a new topic and new curriculum introduce. In this perspective, teacher readiness depends on the maturity and experience of a teacher. Findings from the study by Kondakci et al., (2015) found that teachers with experiences in teaching are more mature and ready to accept changes in educational reform. Majorly studies prove that content knowledge and teacher attitudes are key factors influencing the level of teacher readiness. Based on the discussions, it is clear that the teacher must be ready to effectively deliver the topic's content. According to the reviews, the major factors that influence teacher readiness in the discussion are teacher content knowledge and teacher attitudes. As a result, the two variables will be the focus of this study. By all means, teacher readiness will determine the success or failure of the new curriculum. It is also parallel to the demands of the national education system because curricula are constantly changing to keep up with global education development. Thus, the researcher needs to develop 
an instrument to study the level of teacher readiness to teach QP in terms of their content knowledge and attitudes. This instrument is also expected to contribute and guide to researchers or teachers who want to study the level of teacher readiness to teach QP in terms of the same variables to improve the quality of QP teaching.

\section{Rasch Measurement Model}

The Rasch Measurement Model (RMM) was used to assess the validity and reliability of TRQP instrument items. In the study by Planinic et al. (2019), they claimed that Physics Education Research practitioners are not new in the use of the Rasch model for data analysis. The Rasch Measurement Model is an effective solution for preparing high validity and reliability of the instrument by producing detailed statistics (Bond \& Fox, 2015). RMM assessed each respondent's ability to answer the instrument and measured the difficulty of each item on the instrument (Green \& Frantom, 2002). Furthermore, RMM can detect latent traits such as human thoughts and feelings (Planinic et al., 2019).

RMM, which is based on Item Response Theory, is one of the statistical models that can measure the difficulty of the item as well as the ability of the person being tested at the same time (Testa et al., 2019). As a result, the RMM was able to determine the validity as well as the item and respondent reliability. Rasch analysis can also be used to determine the construct validity based on item polarity, item fit, person fit, and unidimensionality.

Rasch analysis takes longer than traditional analysis, however it provides a more in-depth understanding of the strengths and weaknesses of instruments (Boone, 2016). According to Bond and Fox (2015), RMM is an effective solution for developing highly valid and reliable instruments through statistical analysis. Furthermore, the importance of the Rasch model is that it is not simply an advanced statistical methodology, but that it serves as a way of perceiving and answering questions about what measurement is, as well (Planinic et al., 2019). Thus, the researcher uses Rasch analysis to analyze the validity and reliance of the TRQP instrument based on these strengths.

\section{Research Objective}

The purpose of this study was to evaluate the reliability and validity of the instrument of Teacher Readiness to Teach Quantum Physics (TRQP) using the Rasch Measurement Model (RMM). In particular, the objectives of the study were to:

i. Evaluate the reliability of TRQP instruments using Rasch analysis.

ii. Assess the validity of the TRQP instrument using Rasch analysis.

\section{Methodology}

\section{Instrumentation}

Items were generated from the literature related to quantum physics and teacher readiness in terms of their content knowledge and attitudes. Researchers have adapted an instrument from several instruments in order to find out the level of teacher readiness to teach quantum physics in terms of content knowledge and attitudes. In order to bring the original context into line with the school environment and teachers as respondents, the measurement items are modified based on the literature review. The instrument consists of 41 items on a 10-point interval scale ranging from $1=$ strongly disagree to $10=$ strongly agree which measures the teacher's content knowledge, attitudes, and readiness. The teacher's content knowledge was measured using a 21-item established by Sezgin Selçuk and Çalýskan (2009). The items for content knowledge also modified by referring to the national physics curriculum documents which are the Dokumen Standard Kurikulum dan Pentaksiran (DSKP). Teacher's attitudes were assessed using a 10-item measure adapted from Mohd Yusof and Ibrahim (2012). Teacher's 
readiness was assessed using a 10-item measure adapted from Veloo et al. (2015). Table 3 shows the items in the proposed research instrument.

Table 3: The Proposed Research Instrument

\begin{tabular}{|c|c|}
\hline Construct & Items \\
\hline Content & Quantum physics is the world of probabilities. \\
\hline \multirow[t]{20}{*}{ Knowledge } & Quantum physics is a theory that consists only of advanced mathematics. \\
\hline & Quantum physics is totally independent from classical physics. \\
\hline & Quantum physics is the most fundamental resources of technology today. \\
\hline & Quantum physics is a superior theory also consists of classical physics. \\
\hline & Electrons are always behaving as particles. \\
\hline & Electrons can be around the nucleus anywhere at any time. \\
\hline & Electrons are negatively charged spherical particles that move in clouds. \\
\hline & By knowing position of an electron, we can estimate behaviour of the electron. \\
\hline & Light always behaves as waves. \\
\hline & Light consist of small 'energy packages', light quanta. \\
\hline & $\begin{array}{l}\text { When an electron passes through a narrow slit then projected onto a screen, a } \\
\text { diffraction pattern is produced. }\end{array}$ \\
\hline & $\begin{array}{l}\text { Type of experiment performed determine behaviour of an electron as waves or } \\
\text { as particles. }\end{array}$ \\
\hline & Atoms can absorb energy only in portions of a certain amount. \\
\hline & Atoms can absorb energy when electrons have enough kinetic energy. \\
\hline & $\begin{array}{l}\text { There is no way to know the particle energy until an energy measurement is } \\
\text { performed. }\end{array}$ \\
\hline & $\begin{array}{l}\text { Movement of electrons in an atom is similar to the movement of planets orbiting } \\
\text { the sun. }\end{array}$ \\
\hline & $\begin{array}{l}\text { The energy of a photon is transferred to an electron as one portion, which is an } \\
\text { indication of the particle nature of light. }\end{array}$ \\
\hline & $\begin{array}{l}\text { Electrons in metal can receive radiation energy only as packages of a certain } \\
\text { size, which was dependent only on the frequency of the radiation. }\end{array}$ \\
\hline & $\begin{array}{l}\text { In the photoelectric effect, light's photon is absorbed into an atom and detaches } \\
\text { an electron from it. }\end{array}$ \\
\hline & $\begin{array}{l}\text { Blackbody emits energy in the form of electromagnetic radiation caused by the } \\
\text { thermal motion of charged particles. }\end{array}$ \\
\hline \multirow[t]{10}{*}{ Attitudes } & I have adequate information about the topic of quantum physics. \\
\hline & I need extra teaching aids to facilitate my teaching quantum physics. \\
\hline & I will use only textbook to teach the topic of quantum physics in class. \\
\hline & I feel comfortable use different resources to teach the topic of quantum physics. \\
\hline & It is worth to do self-study before teaching the quantum physics topic. \\
\hline & $\begin{array}{l}\text { I am willing to search additional information through website to ensure the topic } \\
\text { is easy for students to understand. }\end{array}$ \\
\hline & I think it is easy to deliver the knowledge of quantum physics. \\
\hline & $\begin{array}{l}\text { I can teach the topic of quantum physics in a favourable situation to assist the } \\
\text { students. }\end{array}$ \\
\hline & I am interested to enrol in training to improve my teaching skills. \\
\hline & I will discuss with physics colleagues before going to classroom. \\
\hline \multirow[t]{6}{*}{ Readiness } & I plan to use simple techniques in teaching the topic of quantum physics. \\
\hline & I plan to use hands on techniques in teaching the topic of quantum physics. \\
\hline & $\begin{array}{l}\text { I plan to prepare variety of questions to fulfil my low achievement student in } \\
\text { learning quantum physics. }\end{array}$ \\
\hline & $\begin{array}{l}\text { I plan to prepare same set of questions for all level of achievement in learning of } \\
\text { quantum physics. }\end{array}$ \\
\hline & $\begin{array}{l}\text { I plan to utilize the textbook in teaching and learning methods to attract students' } \\
\text { interest. }\end{array}$ \\
\hline & I plan to utilize the technology in teaching and learning methods to attract \\
\hline
\end{tabular}


students' interest in learning the topic of quantum physics.

I plan to use variety of teaching resources to enhance the teaching and learning.

I plan to use just one type of teaching resources in order to align it with the

quantum physics topics needs.

I plan to use videos in the teaching and learning process to visualize abstract quantum phenomena to students.

I plan to draw in the teaching and learning process to visualize abstract quantum phenomena to students.

\section{Sample of the Study}

The Rasch analysis was conducted based on the data collected from a pilot study with a total number of of 30 Form Five Physics teachers from secondary schools in Sabah.

\section{Data Analysis Procedure}

The findings of the study were analyzed to determine the reliability and validity from the aspect of validity content and validity of constructs. To determine the content validity consent value, the researcher using the Content Validity Index (CVI). CVI gives an average evaluation score for all items evaluated by experts. The number of experts who review an instrument is recommended for 2 to 20 persons (Armstrong, Cohen, Eriksen, \& Cleeland, 2005). However, Zamanzadeh et al. (2015) state that at least five experts are recommended for reviewing the instrument to evaluate the chance agreement reasonably. Thus, the content validity was determined using a number of experts $(n=5)$ that included experts in Physics Education and statistics. Content validity was determined based on CVI data indicating high validity for the items (Shrotryia \& Dhanda, 2019). CVI analysis is based on the formula shown below (Yusoff, 2019). The CVI score of above 0.80 indicates that all items in the questionnaire are relevant, clear, and understandable for teachers (Lau et al., 2018; Marzuki et al., 2018; Shrotryia \& Dhanda, 2019).

\section{$\mathrm{I}-\mathrm{CVI}=($ agreed item $) /$ (number of expert)}

WINSTEPS software version 3.72 .3 is used to determine aspects of construct validity and item reliability. This ensures that the instrument is assured of quality and that the data obtained by the researchers are accurate before they are used in an actual study.

To begin, a PTMEA-CORR value analysis was performed to determine item polarity. A positive PTMEA-CORR value indicates that the item can measure what it wants to measure well, whereas a negative value indicates that the item cannot measure what it wants to measure. Item fit was assessed using the values MNSQ Outfit, ZSTD Outfit, and PTMEA-CORR (Bond \& Fox, 2007; Boone, Yale, \& Staver, 2014; Hassan, Puteh, Muhamad Sanusi, \& Che Mohamad Zahid, 2019). This item's fit value indicates whether the item is capable of measuring that it should be capable of performing (Sumintono \& Widhiarso, 2015). Items that do not fall within the scope of The Item Fit Index (Table 4) must be changed or removed in order to improve the item fit value (Sumintono \& Widhiarso, 2015).

Table 4: Fit Indices for Item Fit Statistics

\begin{tabular}{lc}
\hline Statistics & Fit Indices \\
\hline Outfit mean square values (MNSQ) & $0.50-1.50$ \\
Outfit z-standardized values (ZSTD) & $-2.00-2.00$ \\
Pont Measure Correlation (PTMEA-CORR) & $0.40-0.85$ \\
\hline
\end{tabular}

Source : Boone et al. (2014)

Furthermore, the Rasch model can reveal the person fit based on values such as 'MEASURE,' Outfit MNSQ, and Outfit ZSTD (Yasin, Yunus, \& Ismail, 2018). According to Boone (2016), if the ZSTD Outfit value is greater than 2.0 and the MEASURE value is high, there is a chance that a teacher with a 
background in quantum physics may not respond with caution to low-level items. If the value of Outfit ZSTD exceeds 2.0 but the value of MEASURE is low, teachers with no background in quantum physics will likely be able to correctly answer the 'difficult' item. As a result, inappropriate respondents will be eliminated in order to improve the validity of the instruments (Boone et al., 2014).

Researchers also evaluated the instrument's unidimensionality to ensure that it could truly measure the level of teacher readiness (Muhammad Sukri Saud et al., 2018; Sumintono \& Widhiarso, 2015). Principal Component Analysis (PCA) analysis provides unidimensionality criteria based on 'raw variance explained by measures' (Sumintono, 2016; Sumintono \& Widhiarso, 2015). Accepted values for 'raw variance explained by measures' should be greater than $20 \%$, better if greater than $40 \%$, and excellent if greater than $60 \%$. Meanwhile, the value for 'unexplained variance in first contrast' cannot be greater than 15\%. Table 5 shows the Unidimensionality based on Raw Variance Explained by Measures.

Table 5: Unidimensionality based on Raw Variance Explained by Measures

\begin{tabular}{cc}
\hline Value & Interpretation \\
\hline$>20 \%$ & Acceptable \\
$>40 \%$ & Good \\
$>60 \%$ & Excellent \\
\hline
\end{tabular}

Source: Sumintono and Widhiarso (2015)

As regards the reliability, the researcher refers to Sumintono and Widhiarso (2015) for Cronbach's Alpha values (KR-20), item and respondent reliability indices as well as item separation and person as shown in Table 6.

Table 6: Reliability in Rasch Analysis

\begin{tabular}{lll}
\hline Statistics & Fit Indices & Interpretation \\
\hline Cronbach Alpha (KR-20) & $<0.5$ & Low \\
& $0.5-0.6$ & Moderate \\
& $0.6-0.7$ & Good \\
& $0.7-0.8$ & High \\
& $>0.8$ & Very high \\
\hline Item and Person Reliability & $<0.67$ & Low \\
& $0.67-0.80$ & Sufficient \\
& $0.81-0.90$ & Good \\
& $0.91-0.94$ & Very good \\
& $>0.94$ & Excellent \\
\hline \multirow{3}{*}{ Item and Person Separation } & & High separation value indicates that the \\
& & instrument has a good quality since it can \\
& & identify the group of item and respondent \\
\hline
\end{tabular}

\section{Result of the Study}

\section{Instrument Content Validity}

The content validity is to aim the consistency of the content and with the definition of the variable and the sample of subjects to be measured (Fraenkel, Wallen, \& Hyun, 2012). Face validity is the easiest type of validity to establish where judgment by the scientific community is required to confirm that the 
indicator really measures the construct (Djamba \& Neuman, 2014). Criterion validity refers to the extent to which test scores can be used to predict certain criteria (Taherdoost, 2018).

The complete questionnaire was reviewed by two physics experts; a senior lecturer from IPG Kent Tuaran and a UTM's professor for content validity and face validity to ensure that the measures are suitable for the intended purpose and understandable. The criterion validity was determined by the professor from UMS and senior lecturer from UNISZA, who is a statistician and confirmed that the scales used to measure data are suitable for the statistical analysis and provide the score of agreement for every item. The five experts were asked to give a score of 0 (item not relevant) to 10 (item very relevant). The experts made some relevant comments for some of the questions to be shortened and reworded to avoid double-barrelled questions. The questionnaire was reviewed accordingly and revised based on the suggestions of the experts and the researcher further pilot test the questionnaire to 30 physics teachers in Sabah.

Based on Table 7, the content validity index values were obtained after going through expert validation is 0.95 . The high content validity index (CVI) of the questionnaires thus indicates the content is well adopted into local context and translated using clear and understandable sentences. In this evaluation process, no items were rejected, and 10 items were rephrased to improve readability.

Table7 : Content validity index (CVI) based on the rating of the relevancy of items by 5 experts

\begin{tabular}{lcc}
\hline & Items & CVI \\
\hline Content Knowledge & & 1.000 \\
Attitudes & & 1.000 \\
Readiness to Teach & 0.800 \\
\hline Average CVI & 0.951 \\
\hline
\end{tabular}

\section{Instrument Construct Validity}

\section{Item Polarity}

The aim of checking the Point Measure correlation value (PTMEA CORR.) is to detect the item's polarity and to see how well the construct's development accomplishes its target. According to Bond and Fox (2007), a high PTMEA-CORR value, such as 0.4-0.85, means that the item can differentiate between study subjects and that the item construction can calculate what should be measured. However, according to Bond \& Fox (2015), if the PTMEA CORR value is positive (+), the item calculates the construct you want to calculate. On the other hand, if the value obtained is negative (-), it indicates that the created item does not calculate the construct being measured. The item must then be fixed or discarded because it is not geared to questions or is difficult for the respondent to answer. The PTMEA CORR values are shown in Figure 1.

From Figure 1, all items are positive PTMEA-CORR ranging from 0.25 to 0.56 . All the items were found to be within the agreed point measure correlation range of 0.4 to 0.85 . This is confirmed by Bond and Fox (2007), who state that a positive PTMEA-CORR value indicates that the item measures the desired construct. 
Figure 1: Item Polarity Value Analysis

INPUT: 30 Person 41 Item REPORTED: 30 Person 41 Item 10 CATS WINSTEPS 3.72 .3

Person: REAL SEP.: 3.42 REL.: $.92 \ldots$ Item: REAL SEP.: 2.57 REL.: .87

Item STATISTICS: CORRELATION ORDER

\begin{tabular}{|c|c|c|c|c|c|c|c|c|c|c|c|c|c|}
\hline \multirow{2}{*}{$\begin{array}{l}\text { ENTRY } \\
\text { NUMBER }\end{array}$} & \multirow{2}{*}{$\begin{array}{l}\text { TOTAL } \\
\text { SCORE }\end{array}$} & TOTAL & \multirow[b]{2}{*}{ MEASURE } & \multirow{2}{*}{$\begin{array}{l}\text { MODEL } \\
\text { S.E. | }\end{array}$} & \multicolumn{2}{|c|}{ INFIT } & \multicolumn{2}{|c|}{ OUTFIT } & \multicolumn{2}{|c|}{ |PT-MEASURE } & \multicolumn{2}{|c|}{ | EXACT MATCH | } & \multirow[b]{2}{*}{ Item } \\
\hline & & COUNT & & & MNSQ & ZSTD & MNSQ & ZSTD & |CORR. & EXP. & OBS\% & EXP\%| & \\
\hline & & & & & & & & & $\cdots$ & & & & \\
\hline 35 & 243 & 30 & .15 & .13 & 1.29 & 1.1 & 1.46 & 1.3 & .25 & .45 & 16.7 & $28.5 \mid$ & R4 \\
\hline 26 & 280 & 30 & -.82 & .21| & .95 &.$\theta$ & 1.29 & .7 & .27 & .30 & 43.3 & $43.4 \mid$ & A5 \\
\hline 24 & 271 & 30 & -.48 & .18| & | 1.09 & .4 & 1.53 & 1.2 & .27 & .35 & 36.7 & $35.6 \mid$ & A3 \\
\hline 36 & 260 & 30 & -.19 & .15 & 1.31 & 1.0 & 1.52 & 1.3 & .28 & .40 & 30.0 & 33.0 & R5 \\
\hline 31 & 270 & 30 & -.45 & .17| & | .84 & $-.4 \mid$ & .95 & .0 & .33 & .35 & 43.3 & $35.6 \mid$ & A10 \\
\hline 11 & 258 & 30 & -.14 & .15 & 1.51 & 1.6 & 1.43 & 1.1 & .36 & .40 & 40.0 & $32.9 \mid$ & C11 \\
\hline 27 & 276 & 30 & -.65 & .19 & | .99 & .1 & .89 & -.1 & .37 & .32 & 43.3 & 39.21 & A6 \\
\hline 3 & 238 & 30 & .23 & .13| & |1.70 & 2.2 & 1.55 & 1.5 & .40 & .47 & 20.0 & $28.1 \mid$ & C3 \\
\hline 39 & 211 & 30 & .62 & .11| & |1.39 & 1.5 & 1.46 & 1.4 & .40 & .53 & 23.3 & $27.1 \mid$ & R8 \\
\hline 34 & 262 & 30 & -.24 & .16 & | .91 & -.2 & 1.20 & .6 & .40 & .39 & 46.7 & $33.5 \mid$ & R3 \\
\hline 2 & 185 & 30 & .94 & $.11 \mid$ & $\mid 1.71$ & 2.5 & 1.76 & 2.3 & .41 & .58 & 16.7 & 20.5 & $\mathrm{C} 2$ \\
\hline 17 & 235 & 30 & .28 & .13| & 1.13 & .6 & 1.42 & 1.2 & .41 & .47 & 40.0 & $27.8 \mid$ & C17 \\
\hline 13 & 260 & 30 & -.19 & $.15 \mid$ & .85 & $-.4 \mid$ & .83 & -.3 & .41 & .40 & 40.0 & $33.0 \mid$ & C13 \\
\hline 4 & 243 & 30 & .15 & .13| & $\mid 1.20$ & .8 & 1.26 & .8 & .42 & .45 & 10.0 & $28.5 \mid$ & C4 \\
\hline 5 & 229 & 30 & .37 & . $12 \mid$ & | 1.26 & 1.0 & 1.07 & .3 & .42 & .49 & 36.7 & $29.0 \mid$ & C5 \\
\hline 6 & 224 & 30 & .45 & .12| & | 1.27 & 1.0 & 1.36 & 1.1 & .42 & .50 & 23.3 & $28.2 \mid$ & C6 \\
\hline 33 & 235 & 30 & .28 & .13| & |1.02 & .2 & 1.44 & 1.3 & .43 & .47 & 23.3 & $27.8 \mid$ & R2 \\
\hline 12 & 271 & 30 & -.48 & .18| & .65 & -1.1 & .63 & -.8 & .43 & .35 & 50.0 & 35.6 & C12 \\
\hline 30 & 273 & 30 & -.55 & .18| & .97 &.$\theta$ & .90 & -.1 & .44 & .34 & 30.0 & 35.5 & A9 \\
\hline 40 & 275 & 30 & -.62 & .19| & .79 & -.5 & .62 & -.8 & .44 & .33 & 53.3 & $36.6 \mid$ & R9 \\
\hline 41 & 249 & 30 & .04 & .14| & .94 & $-.1 \mid$ & 1.10 & .4 & .44 & .43 & 36.7 & $30.8 \mid$ & R10 \\
\hline 37 & 270 & 30 & -.45 & |17| & .86 & $-.3 \mid$ & .73 & -.5 & .44 & .35 & 36.7 & $35.6 \mid$ & $\mathrm{R} 6$ \\
\hline 16 & 247 & 30 & .08 & .14 & .87 & -.4 & .96 &.$\theta$ & .45 & .44 & 33.3 & 29.9 & C16 \\
\hline 25 & 260 & 30 & -.19 & .15 & 1.19 & $.7 \mid$ & 1.07 & .3 & .45 & .40 & 30.0 & $33.0 \mid$ & A4 \\
\hline 38 & 271 & 30 & -.48 & .18 & .72 & -.8 & .60 & -.9 & .46 & .35 & 43.3 & $35.6 \mid$ & R7 \\
\hline 18 & 251 & 30 & .00 & | 14 & |1.08 & .4 & .98 & .1 & .46 & .43 & 33.3 & $30.8 \mid$ & C18 \\
\hline 29 & 214 & 30 & .58 & |11| & |1.29 & 1.1 & 1.25 & .9 & .46 & .52 & 16.7 & $28.3 \mid$ & A8 \\
\hline 1 & 227 & 30 & .40 & .12| & | .65 & $-1.4 \mid$ & 1.60 & 1.7 & .47 & .49 & 20.0 & $28.7 \mid$ & C1 \\
\hline 15 & 241 & 30 & .18 & |13| & |1.23 & .9 & 1.24 & .8 & .47 & .46 & 26.7 & $28.6 \mid$ & C15 \\
\hline 28 & 257 & 30 & -.12 & |15| & |1.16 & .6 & 1.11 & .4 & .49 & .41 & 26.7 & $32.9 \mid$ & A7 \\
\hline 22 & 268 & 30 & -.39 & .17| & | .86 & -.4 & .73 & -.6 & .49 & .36 & 26.7 & $35.6 \mid$ & A1 \\
\hline 10 & 249 & 30 & .04 & | & .63 & -1.4 & .73 & -.7 & .49 & .43 & 53.3 & $30.8 \mid$ & C10 \\
\hline 8 & 266 & 30 & -.34 & .16 | & .54 & -1.6 & .57 & -1.1 & .50 & .37 & 33.3 & 35.2 & C8 \\
\hline 32 & 261 & 30 & -.21 & .15 | & .70 & -1.0 & .64 & -.9 & .51 & .39 & 30.0 & $33.1 \mid$ & R1 \\
\hline 19 & 245 & 30 & .12 & .13| & .90 & -.3 & .81 & -.4 & .53 & .45 & 23.3 & 28.4 & C19 \\
\hline 20 & 237 & 30 & .25 & .13 & .93 & -.2 & .90 & -.2 & .53 & .47 & 26.7 & 28.1 & C20 \\
\hline 7 & 236 & 30 & .27 & |13| & |1.16 & .7 & .93 & -.1 & .53 & .47 & 23.3 & $27.8 \mid$ & C7 \\
\hline 9 & 251 & 30 & .00 & .14| & | .97 & .0 & .88 & -.2 & .54 & .43 & 36.7 & $30.8 \mid$ & C9 \\
\hline 23 & 162 & 30 & 1.21 & .11 & 1.12 & .6 & 1.14 & .6 & .55 & .62 & 23.3 & $26.1 \mid$ & A2 \\
\hline 21 & 244 & 30 & .13 & .13 & .61 & -1.5 & .57 & -1.3 & .55 & .45 & 26.7 & $28.5 \mid$ & C21 \\
\hline 14 & 241 & 30 & .18 & .13| & | .53 & -1.9 & .55 & -1.4 & .56 & .46 & 30.0 & $28.6 \mid$ & C14 \\
\hline MEAN & 247.5 & 30.0 & .00 & .15 & 1.02 & . 1 & 1.07 & .3 & & & 31.8 & 31.4 & \\
\hline S.D. & 24.0 &.$\theta$ & .43 & .03| & | .28 & 1.0 & .33 & .9 & & & 10.3 & 4.1 & \\
\hline
\end{tabular}

\section{Fit Statistics}

According to Bond and Fox (2007), the outlier-sensitive statistic (outfit statistic) reveals a large difference between the observed and expected values of an item that is outside the range of the individual's ability, whereas the information-weighted fit statistic (infit statistic) reveals the residual of an item that is within the range of the person's ability. The outfit statistic of Mean Square (MNSQ), according to Planinic et al. (2019), offers a more pronounced calculation than the infit statistics in Rasch 
DOI: https://doi.org/10.47405/mjssh.v6i5.775

analysis. Aside from the MNSQ infit and outfit values, the infit and outfit of Z-Standardized (ZTSD) should be in the -2 to +2 range. However, if the MNSQ value meets the criteria for item suitability and sample adequacy, the ZSTD value may be ignored (Bond \& Fox, 2007; Linacre, 2002). Figure 2 shows the item fit measurement.

Figure 2: Measurement of Item Misfit Order

INPUT: 30 Person 41 Item REPORTED: 30 Person 41 Item 10 CATS WINSTEPS 3.72 .3

Person: REAL SEP.: 3.42 REL.: $.92 \ldots$ Item: REAL SEP.: 2.57 REL.: .87

Item STATISTICS: MISFIT ORDER

\begin{tabular}{|c|c|c|c|c|c|c|c|c|c|c|c|c|c|}
\hline \multirow{2}{*}{$\begin{array}{l}\text { | ENTRY } \\
\text { | NUMBER }\end{array}$} & \multirow{2}{*}{$\begin{array}{l}\text { TOTAL } \\
\text { SCORE }\end{array}$} & \multirow{2}{*}{$\begin{array}{l}\text { TOTAL } \\
\text { COUNT }\end{array}$} & \multirow[b]{2}{*}{ MEASURE } & \multirow{2}{*}{$\begin{array}{l}\text { MODEL } \\
\text { S.E. }\end{array}$} & \multicolumn{2}{|c|}{ INFIT } & \multicolumn{2}{|c|}{ OUTFIT } & \multicolumn{2}{|c|}{ PT -MEASURE } & \multirow{2}{*}{$\begin{array}{r}\text { EXACT } \\
\text { OBS\% }\end{array}$} & \multirow{2}{*}{$\begin{array}{r}\text { MATCH| } \\
\text { EXP\%| }\end{array}$} & \multirow[b]{2}{*}{ Item } \\
\hline & & & & & |MNSQ & ZSTD| & MNSQ & ZSTD|C & CORR. & EXP. I & & & \\
\hline 2 & 185 & 30 & .94 & .11 & 1.71 & 2.5 & 1.76 & $2.3 \mid A$ & A. .41 & .58 & 16.7 & 20.5 & $\mathrm{C} 2$ \\
\hline 3 & 238 & 30 & .23 & .13 & 1.70 & $2.2 \mid$ & 1.55 & $1.5 \mathrm{~B}$ & B . 40 & $.47 \mid$ & 20.0 & 28.1 & C3 \\
\hline 1 & 227 & 30 & .40 & .12 & | . .65 & -1.4 & 1.60 & $1.7 \mid \mathrm{C}$ & C. .47 & .49| & 20.0 & $28.7 \mid$ & C1 \\
\hline 24 & 271 & 30 & -.48 & .18 & |1.09 & .4 & 1.53 & $1.2 \mid \mathrm{D}$ & D .27 & $.35 \mid$ & 36.7 & $35.6 \mid$ & A3 \\
\hline 36 & 260 & 30 & -.19 & .15 & |1.31 & $1.0 \mid$ & 1.52 & $1.3 \mid \mathrm{E}$ & E .28 & $.40 \mid$ & 30.0 & $33.0 \mid$ & R5 \\
\hline 11 & 258 & 30 & -.14 & .15 & 1.51 & $1.6 \mid$ & 1.43 & $1.1 \mid \mathrm{F}$ & F .36 & $.40 \mid$ & 40.0 & $32.9 \mid$ & C11 \\
\hline 35 & 243 & 30 & .15 & .13 & |1.29 & $1.1 \mid$ & 1.46 & $1.3 \mid \mathrm{C}$ & G . .25 & .45 & 16.7 & 28.5 & R4 \\
\hline 39 & 211 & 30 & .62 & .11 & |1.39 & 1.5 & 1.46 & $1.4 \mid \mathrm{r}$ & H . 40 & .53| & 23.3 & $27.1 \mid$ & R8 \\
\hline 33 & 235 & 30 & .28 & .13 & 1.02 & $.2 \mid$ & 1.44 & $1.3 \mid I$ & I . .43 & .47| & 23.3 & $27.8 \mid$ & R2 \\
\hline 17 & 235 & 30 & .28 & .13 & 1.13 & $.6 \mid$ & 1.42 & $1.2 \mid J$ & 丁 .41 & $.47 \mid$ & 40.0 & 27.8 & C17 \\
\hline 6 & 224 & 30 & .45 & .12 & |1.27 & $1.0 \mid$ & 1.36 & $1.1 \mid \mathrm{K}$ & K .42 & $.50 \mid$ & 23.3 & 28.2 & C6 \\
\hline 26 & 280 & 30 & -.82 & .21 & | .95 &.$\theta$ & 1.29 & $.7 \mid \mathrm{L}$ & L .27 & $.30 \mid$ & 43.3 & $43.4 \mid$ & A5 \\
\hline 29 & 214 & 30 & .58 & .11 & |1.29 & $1.1 \mid$ & 1.25 & $.9 \mid \mathrm{N}$ & M.46 & $.52 \mid$ & 16.7 & $28.3 \mid$ & A8 \\
\hline 5 & 229 & 30 & .37 & .12 & |1.26 & $1.0 \mid$ & 1.07 & $.3 \mid \pi$ & N .42 & .49| & 36.7 & $29.0 \mid$ & C5 \\
\hline 4 & 243 & 30 & .15 & .13 & $\mid 1.20$ & $.8 \mid$ & 1.26 & $.8 \mid 0$ & 0.42 & .45 & 10.0 & 28.5 & C4 \\
\hline 15 & 241 & 30 & .18 & .13 & $\mid 1.23$ & .9 & 1.24 & $.8 \mid \mathrm{P}$ & P. .47 & .46 & 26.7 & $28.6 \mid$ & C15 \\
\hline 34 & 262 & 30 & -.24 & .16 & | .91 & $-.2 \mid$ & 1.20 & $.6 \mid c$ & Q . .40 & .39| & 46.7 & $33.5 \mid$ & R3 \\
\hline 25 & 260 & 30 & -.19 & .15 & |1.19 & $.7 \mid$ & 1.07 & $.3 \mid R$ & R . .45 & $.40 \mid$ & 30.0 & $33.0 \mid$ & A4 \\
\hline 7 & 236 & 30 & .27 & .13 & |1.16 & $.7 \mid$ & .93 & $-.1 \mid s$ & S. .53 & .47| & 23.3 & $27.8 \mid$ & C7 \\
\hline 28 & 257 & 30 & -.12 & .15 & 1.16 & $.6 \mid$ & 1.11 & . $4 \mid \mathrm{T}$ & Т . .49 & $.41 \mid$ & 26.7 & $32.9 \mid$ & A7 \\
\hline 23 & 162 & 30 & 1.21 & .11 & 1.12 & $.6 \mid$ & 1.14 & $.6 \mid \mathrm{l}$ & U . .55 & .62 & 23.3 & 26.1 & A2 \\
\hline 41 & 249 & 30 & .04 & .14 & | .94 & $-.1 \mid$ & 1.10 & $.4 \mid t$ & t . .44 & .43| & 36.7 & $30.8 \mid$ & R10 \\
\hline 18 & 251 & 30 & .00 & .14 & |1.08 & $.4 \mid$ & .98 & $.1 \mid s$ & 5.46 & .43| & 33.3 & $30.8 \mid$ & C18 \\
\hline 27 & 276 & 30 & -.65 & .19 & $\begin{array}{ll} & .99\end{array}$ & .1| & .89 & $-.1 \mid r$ & r. .37 & $.32 \mid$ & 43.3 & $39.2 \mid$ & A6 \\
\hline 30 & 273 & 30 & -.55 & .18 & .97 & .0 & .90 & $-.1 \mid c$ & q . .44 & $.34 \mid$ & 30.0 & 35.5 & A9 \\
\hline 9 & 251 & 30 & .00 & .14 & .97 & .0 & .88 & $-.2 \mid p$ & p . 54 & $.43 \mid$ & 36.7 & $30.8 \mid$ & C9 \\
\hline 16 & 247 & 30 & .08 & .14 & .87 & $-.4 \mid$ & .96 & $. \theta \mid c$ & o. .45 & .44| & 33.3 & $29.9 \mid$ & C16 \\
\hline 31 & 270 & 30 & -.45 & .17 & .84 & $-.4 \mid$ & .95 & $. \theta \mid r$ & n . 33 & $.35 \mid$ & 43.3 & $35.6 \mid$ & A10 \\
\hline 20 & 237 & 30 & .25 & .13 & .93 & $-.2 \mid$ & .90 & $-.2 \mid \mathrm{n}$ & $\mathrm{m} .53$ & .47| & 26.7 & $28.1 \mid$ & $\mathrm{C} 2 \theta$ \\
\hline 19 & 245 & 30 & .12 & .13 & .90 & $-.3 \mid$ & .81 & $-.4 \mid 1$ & 1.53 & .45 & 23.3 & 28.4 & C19 \\
\hline 37 & 270 & 30 & -.45 & .17 & .86 & $-.3 \mid$ & .73 & $-.5 \mid k$ & k. .44 & $.35 \mid$ & 36.7 & $35.6 \mid$ & R6 \\
\hline 22 & 268 & 30 & -.39 & .17 & .86 & $-.4 \mid$ & .73 & $-.6 \mid j$ & j. .49 & $.36 \mid$ & 26.7 & $35.6 \mid$ & A1 \\
\hline 13 & 260 & 30 & -.19 & .15 & .85 & -.4 & .83 & $-.3 \mid i$ & i . .41 & .40 & 40.0 & 33.0 & C13 \\
\hline 40 & 275 & 30 & -.62 & .19 & .79 & $-.5 \mid$ & .62 & $-.8 \mid \mathrm{h}$ & h .44 & .33| & 53.3 & $36.6 \mid$ & R9 \\
\hline 10 & 249 & 30 & .04 & .14 & .63 & $-1.4 \mid$ & .73 & $-.7 \mid g$ & g . .49 & .43| & 53.3 & $30.8 \mid$ & C10 \\
\hline 38 & 271 & 30 & -.48 & .18 & .72 & -.8 & .60 & $-.9 \mid f$ & f. .46 & .35 & 43.3 & $35.6 \mid$ & R7 \\
\hline 32 & 261 & 30 & -.21 & .15 & .70 & -1.0 & .64 & $-.9 \mid \epsilon$ & e .51 & .39| & 30.0 & $33.1 \mid$ & R1 \\
\hline 12 & 271 & 30 & -.48 & .18 & .65 & -1.1 & .63 & $-.8 \mid c$ & d .43 & $.35 \mid$ & 50.0 & $35.6 \mid$ & C12 \\
\hline 21 & 244 & 30 & .13 & .13 & .61 & -1.5 & .57 & $-1.3 \mid c$ & c . .55 & $.45 \mid$ & 26.7 & 28.5 & C21 \\
\hline 8 & 266 & 30 & -.34 & .16 & .54 & -1.6 & .57 & $-1.1 \mid b$ & b . .50 & .37| & 33.3 & 35.2 & $\mathrm{C} 8$ \\
\hline 14 & 241 & 30 & .18 & .13 & .53 & -1.9 & .55 & $-1.4 \mid a$ & a .56 & $.46 \mid$ & 30.0 & $28.6 \mid$ & C14 \\
\hline MEAN & 247.5 & 30.0 & .00 & .15 & |1.02 & $.1 \mid$ & 1.07 & $.3 \mid$ & & & 31.8 & $31.4 \mid$ & \\
\hline S.D. & 24.0 &.$\theta$ & .43 & .03 & | .28 & $1.0 \mid$ & .33 & $.9 \mid$ & & & 10.3 & $4.1 \mid$ & \\
\hline
\end{tabular}

However, if items fulfill one criterion, the item must be retained (Sumintono \& Widhiarso, 2015). As shown in Table 8, each item met at least one criterion. As a result, no item removal occurs in this TRQP instrument. 
DOI: https://doi.org/10.47405/mjssh.v6i5.775

Table 8: Item Misfit Order

\begin{tabular}{ccccl}
\hline Item & $\begin{array}{c}\text { Outfit MNSQ } \\
(\mathbf{0 . 5 0 - 1 . 5 0 )}\end{array}$ & $\begin{array}{c}\text { Outfit ZSTD } \\
(\mathbf{- 2 . 0 - 2 . 0 )}\end{array}$ & $\begin{array}{c}\text { PTMEA-CORR } \\
(\mathbf{0 . 4 0 - 0 . 8 5 )}\end{array}$ & Result \\
\hline C2 & $\mathbf{1 . 7 6}$ & $\mathbf{2 . 3}$ & 0.41 & Retained \\
C3 & $\mathbf{1 . 5 5}$ & 1.5 & 0.40 & Retained \\
A3 & $\mathbf{1 . 5 3}$ & 1.20 & $\mathbf{0 . 2 7}$ & Retained \\
R5 & $\mathbf{1 . 5 2}$ & 1.3 & $\mathbf{0 . 2 8}$ & Retained \\
C11 & 1.43 & 1.10 & $\mathbf{0 . 3 6}$ & Retained \\
R4 & 1.46 & 1.30 & $\mathbf{0 . 2 5}$ & Retained \\
C1 & $\mathbf{1 . 6 0}$ & 1.70 & 0.47 & Retained \\
A5 & 1.29 & 0.70 & 0.27 & Retained \\
A6 & 0.89 & -0.10 & $\mathbf{0 . 3 7}$ & Retained \\
A10 & 0.95 & 0.00 & $\mathbf{0 . 3 3}$ & Retained \\
\hline
\end{tabular}

\section{Confirmation of Dimensionality}

Unidimensionality for a Rasch model is a fundamental requirement and is often identified using the Principal Component Analysis of Rasch Residual (PCAR). The concept of unidimensionality is usually defined as one latent trait that can account for the performance of questionnaires (Testa et al., 2019). By trying to maximize the unidimensional measure, we can greatly improve the data quality and strengthen our analysis (Planinic et al., 2019). The TRQP questionnaire's main component analysis is shown in Figure 3 .

Figure 3: Principal Component Analysis of Rasch Residual (PCAR)

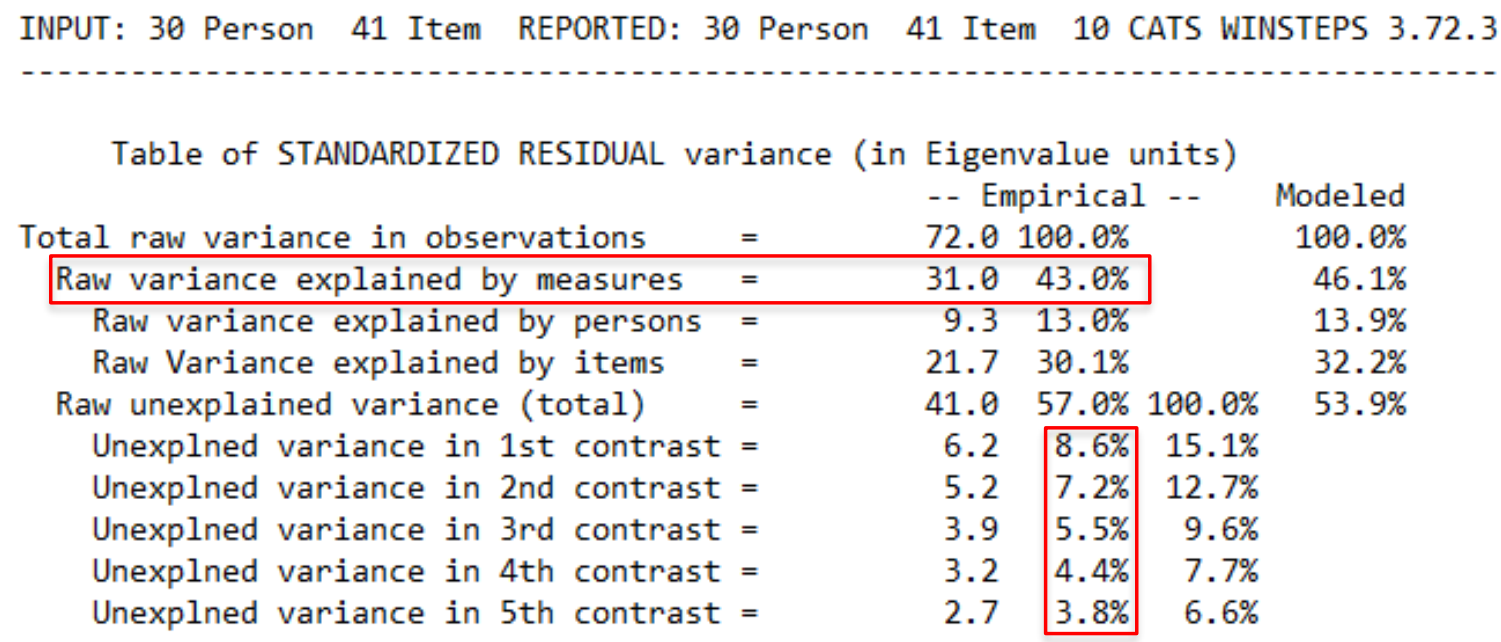

Based on the result in Figure 3, the observed value of the Raw Variance Explained by Measures is 43.0\% which is good stated by Sumintono and Widhiarso (2015). The value of $8.6 \%$ was detected from Unexplained Variance in 1st Contrast, which is less than 15\%. As confirmation, the unexplained variances from 1st contrast to 5th contrast were detected; they are all less than $10 \%$. This demonstrates that the TRQP instrument is free of any ambiguity in terms of the purpose for which this study was conducted and that no second dimension exists for the TRQP instrument.

\section{Reliability and Separation Indices}

Person-measure reliability, which is relevant to the reliability of this research, indicates how well the Physics teacher can be distinguished based on their responses. The reliability of the item measurement 
indicates how well the items (statements), based on their authenticity, can be discriminated against. Table 9 showed the TRQP reliability based on the alpha coefficient (KR-20) of the Cronbach (Cronbach). This value shows that the TRQP questionnaire's reliability is high (Sumintono \& Widhiarso, 2015). Figure 4 describes the reliability and reliability of items with their separation indices.

Figure 4: Result of the Reliability Test

INPUT: 30 Person 41 Item REPORTED: 30 Person 41 Item 10 CATS WINSTEPS 3.72.3

SUMMARY OF 30 MEASURED Person

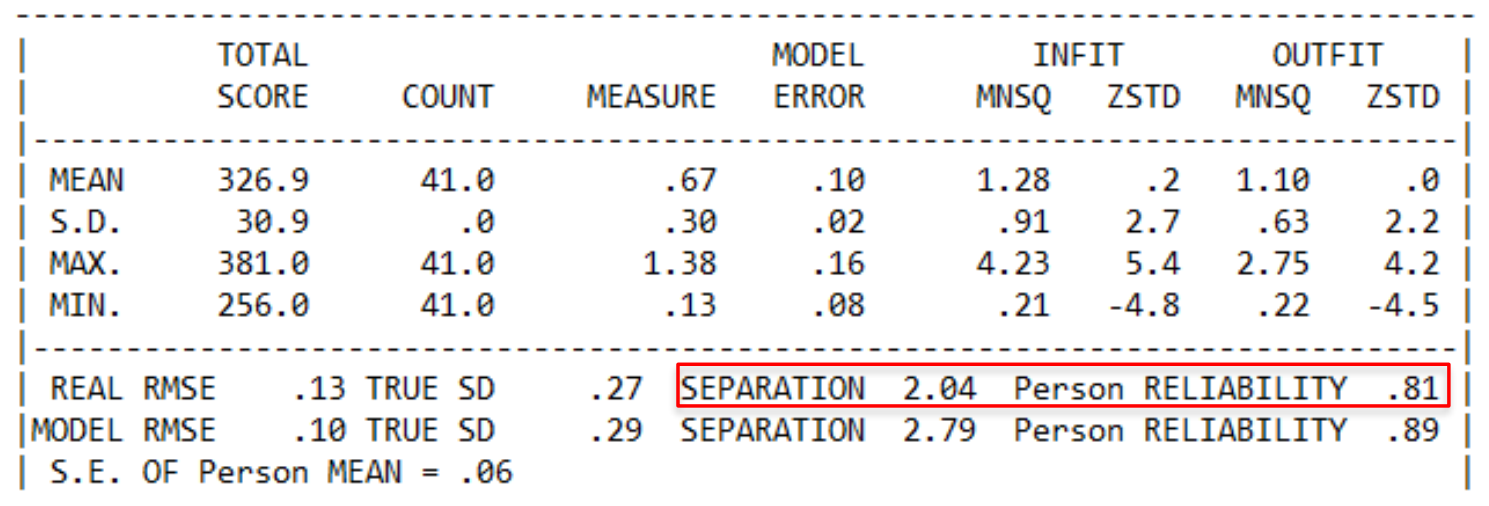

Person RAW SCORE-TO-MEASURE CORRELATION $=.97$

CRONBACH ALPHA (KR-20) Person RAW SCORE "TEST" RELIABILITY $=.87$

SUMMARY OF 41 MEASURED Item

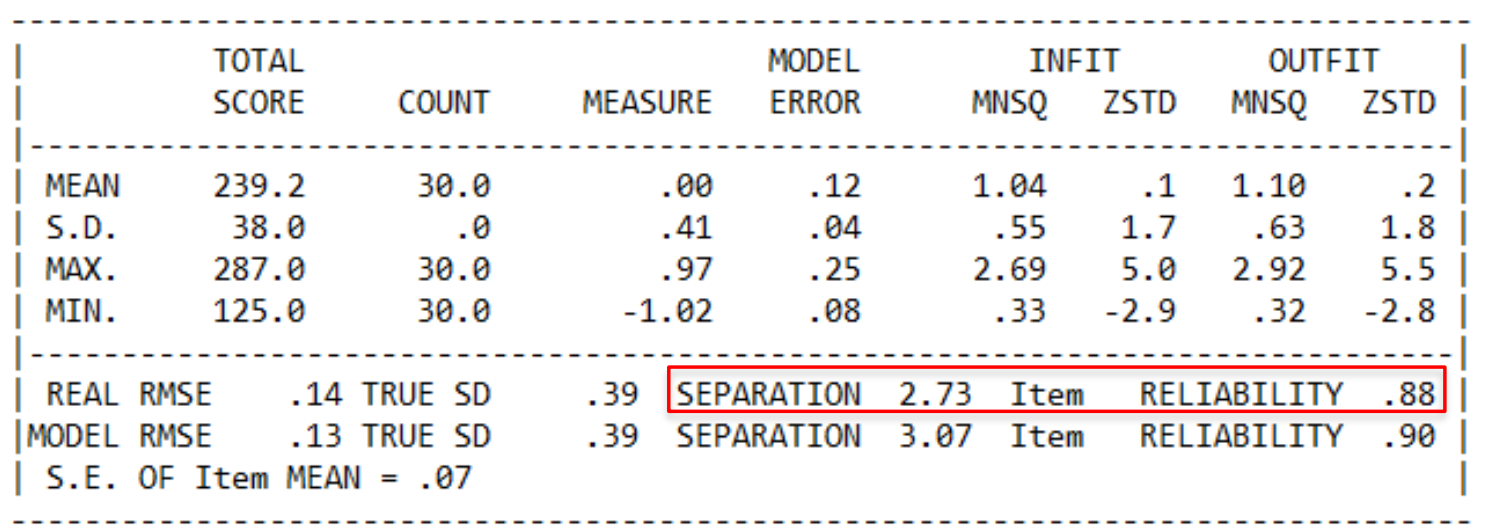

Table 9: Summary of The Reliability Findings

\begin{tabular}{cccc}
\hline & $\begin{array}{c}\text { Rasch } \\
\text { Measurement }\end{array}$ & $\begin{array}{c}\text { TRQP } \\
\text { Questionnaire }\end{array}$ & Interpretation \\
\hline Cronbach Alpha (KR- & $>.80$ & .87 & High \\
20) & $.91-.94$ & .88 & Very good \\
Item Reliability & $>2.0$ & 2.73 & Good \\
Item Separation Index & $.80-.90$ & .81 & Good \\
Person Reliability & $>1.4$ & 2.04 & Good \\
Person Separation & & & \\
Index & & & \\
\hline
\end{tabular}


The researchers had studied further using Wright Maps, as shown in Figure 5, to gain insight into the problems associated with the slightly low person reliability of the TRQP questionnaire.

Figure 5: Wright Map

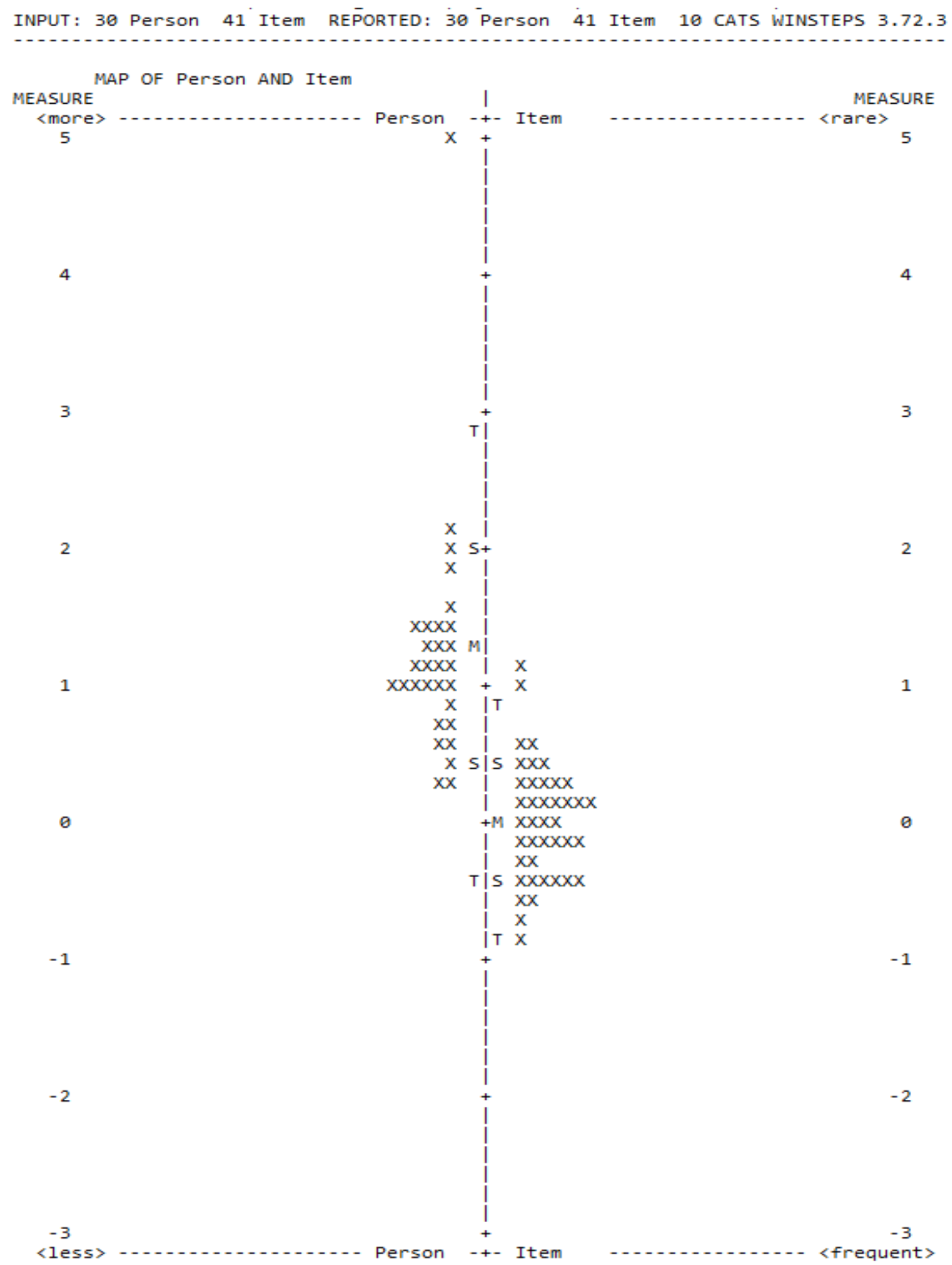

By comparing the range and position of the item-measure distribution to the range and position of the person-measure distribution, the map of persons and items was examined. The person-measure, which extends along the ruler (center vertical dotted line) and is well centered, is illustrated in Figure 5. The distance between the mean person-measure ('M' on the left side) and the mean item-measure ('M' on the right side) is significant. 


\section{Discussion}

On the whole, instrument validity was determined by evaluating the polarity aspect items, item and respondent appropriateness, and unidimensionality. Positive PTMEA-CORR analysis indicates that all items in the TRQP instrument move in the same direction when interpreting a construct to be measured (Bond \& Fox, 2015). All items in the TRQP instrument were retained after item suitability analysis because they fell within the range of one of the criteria MNSQ Outfit, ZSTD Outfit, or PTMEA-CORR. In terms of respondent suitability, only three out of 30 people demonstrated extreme incompatibility and scores with a negative PTMEA-CORR reading. This demonstrates that they are making an unusual decision. However, the subject of this study is still retained due to the possibility of the subject's careless study while answering TRQP items (A Aziz, Ahmad, \& Mat Nashir, 2019).

In terms of reliability, the TRQP instrument has a high Cronbach's Alpha value (0.87), a very good item reliability value (0.88), and good respondent reliability (0.81). These findings indicate that the TRQP instrument is reliable in assessing the level of readiness of Form Five Physics teachers to teach quantum physics in terms of content knowledge and attitudes in secondary schools.

\section{Conclusion}

To ensure that the developed instrument can be used repeatedly, instrument development must be done precisely and correctly in terms of validity and reliability. Instruments that have been properly constructed will have no trouble in measuring the variables being studied (Hassan et al., 2019). This circumstance will undoubtedly aid researchers in concluding the analysis of the findings. Furthermore, these findings provide support for other researchers, allowing Rasch analysis of the TRQP instrument to be performed for physics teachers in other areas. Finally, the results of the validity and reliability analysis using the Rasch Measurement Model successfully demonstrated that the TRQP instrument is valid and can be trusted to measure the level of readiness of teachers to teach quantum physics in secondary school from the perspectives of content knowledge and attitudes.

\section{References}

A Aziz, N. F., Ahmad, H., \& Mat Nashir, I. (2019). Validation of technical and vocational teachers' competency evaluation instrument using the Rasch model. Jurnal Pendidikan Sains Dan Matematik Malaysia, 9(1), 18-25. https://doi.org/10.37134/jpsmm.vol9.1.3.2019

Armstrong, T. S., Cohen, M. Z., Eriksen, L., \& Cleeland, C. (2005). Content validity of self-report measurement instruments: An illustration from the development of the Brain Tumor Module of the M.D. Anderson Symptom Inventory. Oncology Nursing Forum, 32(3), 669-676. https://doi.org/10.1188/05.ONF.669-676

Avidov-Ungar, O., \& Eshet-Alkalai, Y. (2011). Teachers in a World of Change: Teachers' Knowledge and Attitudes towards the Implementation of Innovative Technologies in Schools. Interdisciplinary Journal of E-Skills and Lifelong Learning, 7, 291-303. https://doi.org/10.28945/1525

Bahagian Pembangunan Kurikulum. (2018). Kurikulum Standard Sekolah Menengah Fizik Dokumen Standard Kurikulum dan Pentaksiran Tingkatan 4 dan 5. Putrajaya: bahagian Pembangunan Kurikulum, Kementerian Pendidikan Malaysia.

Balta, N. (2018). High School Teachers' Understanding of Blackbody Radiation. International Journal of Science and Mathematics Education, 16(1), 23-43. https://doi.org/10.1007/s10763-016-9769-z

Bond, T. G., \& Fox, C. M. (2007). Applying the Rasch Model: Fundamental Measurement in the Human Sciences Second Edition University of Toledo.an Sciences Second Edition (Second Edi; University of Toledo, Ed.). London: Lawrnece Erlbaum Associates.

Bond, T. G., \& Fox, C. M. (2015). Applying the Rasch Model Fundamental Measurement in the Human Sciences Third Edition (Third). New York: Taylor \& Francis.

Boone, W. J. (2016). Rasch analysis for instrument development: Why, when, and how? CBE Life Sciences Education, 15(4), 1-7. https://doi.org/10.1187/cbe.16-04-0148 
Boone, W. J., Yale, M. S., \& Staver, J. R. (2014). Rasch analysis in the human sciences. In Rasch Analysis in the Human Sciences. https://doi.org/10.1007/978-94-007-6857-4

Bungum, B., Henriksen, E. K., Angell, C., Tellefsen, C. W., \& Bøe, M. V. (2015). ReleQuant Improving teaching and learning in quantum physics through educational design research. Nordic Studies in Science Education, 11(2), 153. https://doi.org/10.5617/nordina.2043

Calýskan, S., Selçuk, G. S., \& Erol, M. (2009). Student Understanding of Some Quantum Physical Concepts. Latin-American Journal of Physics Education, 3(2), 202-206.

Chieng, Y. E., \& Tan, C. K. (2019). Validation and Reliability of Teacher Readiness, Technology and Pedagogy Knowledge Towards Technology Integration in 21St Century Learning. International Journal of Education, Psychology and Counseling, 4(33), 41-52. https://doi.org/10.35631/ijepc.433004

Daniela, C. C., Popescu, F. F., Ioan, P. A., \& Andrei, V. (2015). Conceptual Maps and Integrated Experiments for Teaching/Learning Physics of Photonic Devices. Procedia - Social and Behavioral Sciences, 191, 512-518. https://doi.org/10.1016/j.sbspro.2015.04.284

Du, X., \& Chaaban, Y. (2020). Teachers' Readiness for a Statewide Change to PjBL in Primary Education in Qatar. Interdisciplinary Journal of Problem-Based Learning, 14(1), 1-15. https://doi.org/10.14434/ijpbl.v14i1.28591

Fan, M., Leung, L. P., Leung, R., Hon, S., \& Fan, K. L. (2019). Readiness of Hong Kong secondary school teachers for teaching cardiopulmonary resuscitation in schools: A questionnaire survey. Hong Kong Journal of Emergency Medicine, 26(3), 174-178. https://doi.org/10.1177/1024907918797532

Fraenkel, J. R., Wallen, N. E., \& Hyun, H. H. (2012). How to Design and Evaluate Research in Education (8th ed.). New York: McGraw Hill.

González-Gómez, D., Jeong, J. S., \& Cañada-Cañada, F. (2019). Enhancing science self-efficacy and attitudes of Pre-Service Teachers (PST) through a flipped classroom learning environment. Interactive Learning Environments, 1-12. https://doi.org/10.1080/10494820.2019.1696843

Green, K. E., \& Frantom, C. G. (2002). Survey Development and Validation With the Rasch Model. International Conference on Questionnaire Development, Evaluation, and Testing, (February), 42.

Hassan, N. F., Puteh, S., Muhamad Sanusi, A., \& Che Mohamad Zahid, N. H. (2019). Student perspective on technology enabled/enhanced active learning in educational: Rasch measurement model. International Journal of Engineering and Advanced Technology, 8(6 Special Issue 3), 929-935. https://doi.org/10.35940/ijeat.F1061.0986S319

Héraud, J. L., Lautesse, P., Ferlin, F., \& Chabot, H. (2017). Representing the Quantum Object Through Fiction in Teaching: The Ontological Contribution of Gamow's Narrative as Part of an Introduction to Quantum Physics. Science and Education, 26(3-4), 299-322. https://doi.org/10.1007/s11191-017-9890-6

Hill, R. J. (1975). Belief, Attitude, Intention, and Behavior: An Introduction to Theory and Research. Reading, MA: Addison-Wesley. Contemporary Sociology, 6(2), 244-245.

Holt, D. T., Armenakis, A. A., Feild, H. S., \& Harris, S. G. (2007). Readiness for organizational change: The systematic development of a scale. Journal of Applied Behavioral Science, 43(2), 232-255. https://doi.org/10.1177/0021886306295295

Holt, D. T., \& Vardaman, J. M. (2013). Toward a Comprehensive Understanding of Readiness for Change: The Case for an Expanded Conceptualization. Journal of Change Management, 13(1), 9-18. https://doi.org/10.1080/14697017.2013.768426

Huoy Tyan, P., Abd Rahman, F., \& Shafie Sarvestani, M. (2020). Teachers' readiness in implementing and facilitating 21st century learning. Universal Journal of Educational Research, 8(1 A), 24-29. https://doi.org/10.13189/ujer.2020.081304

Jwaifell, M. (2019). In-service Science Teachers' Readiness of Integrating Augmented Reality. Journal of Curriculum and Teaching, 8(2), 43. https://doi.org/10.5430/jct.v8n2p43

Kaur, D., \& Zhao, Y. (2017). Development of Physics Attitude Scale (PAS): An Instrument to Measure Students' Attitudes Toward Physics. Asia-Pacific Education Researcher, 26(5), 291-304. https://doi.org/10.1007/s40299-017-0349-y

Kleickmann, T., Tröbst, S., Heinze, A., Bernholt, A., Rink, R., \& Kunter, M. (2017). Teacher Knowledge Experiment: Conditions of the Development of Pedagogical Content Knowledge. https://doi.org/10.1007/978-3-319-50030-0_8

Kondakci, Y., Beycioglu, K., Sincar, M., \& Ugurlu, C. T. (2015). Readiness of teachers for change in 
DOI: https://doi.org/10.47405/mjssh.v6i5.775

schools. International Journal of Leadership in Education, 20(2), 176-197. https://doi.org/10.1080/13603124.2015.1023361

Krijtenburg-Lewerissa, K., Pol, H. J., Brinkman, A., \& van Joolingen, W. R. (2019). Key topics for quantum mechanics at secondary schools: a Delphi study into expert opinions. International Journal of Science Education, 41(3), 349-366. https://doi.org/10.1080/09500693.2018.1550273

Krijtenburg-Lewrissa, K. (2020). Teaching Quantum Mechanics at Secondary Schools. University of Twente.

Lau, A. S. Y., Yusoff, M. S. B., Lee, Y. Y., Choi, S. B., Xiao, J. Z., \& Liong, M. T. (2018). Development and validation of a Chinese translated questionnaire: A single simultaneous tool for assessing gastrointestinal and upper respiratory tract related illnesses in pre-school children. Journal of Taibah University Medical Sciences, 13(2), 135-141. https://doi.org/10.1016/j.jtumed.2017.11.003

Lautesse, P., Vila Valls, A., Ferlin, F., Héraud, J. L., \& Chabot, H. (2015). Teaching Quantum Physics in Upper Secondary School in France: : 'Quanton' Versus 'Wave-Particle' Duality, Two Approaches of the Problem of Reference. Science and Education, 24(7-8), 937-955. https://doi.org/10.1007/s11191-015-9755-9

Linacre, J. M. (2002). Understanding Rasch measurement: Optimizing Rating Scale Category Effectiveness. Journal of Applied Measurement, 3, 85-106.

Michelini, M., Santi, L., \& Stefanel, A. (2014). Teaching modern physics in secondary school. Proceedings of Science, (July), 1-10.

Michelini, M., \& Stefanel, A. (2010). High school students face QM basic concepts. New Trends in Science and Technology Education, 1, 308-322.

Mohamad Marzuki, M. F., Yaacob, N. A., \& Yaacob, N. M. (2018). Translation, Cross-Cultural Adaptation, and Validation of the Malay Version of the System Usability Scale Questionnaire for the Assessment of Mobile Apps. JMIR Human Factors, 5(2), e10308. https://doi.org/10.2196/10308

Mohd Yusof, S. B., \& Ibrahim, N. B. (2012). Kesediaan Guru Matematik Tahun Satu Dalam Pelaksanaan Kurikulum Standard Sekolah Rendah (KSSR) di Daerah Kluang. Journal of Science and Mathematics Education, 6(June), 26-38.

Mousa, R. (2016). Mathematics Teachers' Readiness and Attitudes Toward Implementing Integrated Stem Education in Saudi Arabia: a Mixed Methods Study. https://doi.org/10.1016/j.jpowsour.2008.09.008

Muhammad Sukri Saud, Mohd Rustam Mohd Rameli, Azlina Mohd Kosnin, Noraffandy Yahaya, Yusri Kamin, Megat Aman Zahiri Megat Zakaria, ... Marlissa Omar. (2018). Readiness In Implementing Teacher Training Programmes Based On Industrial Revolution 4.0: Evidence From Malaysian Public Universities. Journal of Engineering Science and Technology, 13(Special Issue on ICITE 2018), 42-48.

Neuman, W. L. (2014). Social Research Methods: Qualitative and Quantitative Approaches. In Teaching Sociology (Seventh). https://doi.org/10.2307/3211488

Nilsson, P., \& van Driel, J. (2011). How Will We Understand What We Teach? - Primary Student Teachers' Perceptions of their Development of Knowledge and Attitudes Towards Physics. Research in Science Education, 41(4), 541-560. https://doi.org/10.1007/s11165-010-9179-0

Park, M., Dimitrov, D. M., Patterson, L. G., \& Park, D. (2016). Early childhood teachers 'beliefs about readiness for teaching science, technology, engineering, and mathematics. Journal of Early Childhood Research, 1-17. https://doi.org/10.1177/1476718X15614040

Planinic, M., Boone, W. J., Susac, A., \& Ivanjek, L. (2019). Rasch analysis in physics education research: Why measurement matters. Physical Review Physics Education Research, 15(2), 20111. https://doi.org/10.1103/PhysRevPhysEducRes.15.020111

Pospiech, G. (2019). Pre-Service Teacher' $s$ Views on the use of Metaphors for Describing the Concepts of Uncertainty and Entanglement in Teaching Quantum Physics. International Journal of Physics and Chemistry Education, 11(1), 1-5.

Rainer, M., \& Wiesner, H. (1999). Students' Conceptions of Quantum Physics. National Association for Research in Science Teaching March, 1999, 13(1), 20-22. https://doi.org/10.1103/PhysRevPhysEducRes.13.010109

Ramli, A. A., Ibrahim, N. H., Surif, J., Bunyamin, M. A. H., Jamaluddin, R., \& Abdullah, N. (2017). Teachers' readiness in teaching STEM education. Man in India, 97(13), 343-350. 
Ramli, N. F., \& Talib, O. (2017). Can Education Institution Implement STEM? From Malaysian Teachers' View. International Journal of Academic Research in Business and Social Sciences, 7(3), 721-732. https://doi.org/10.6007/ijarbss/v7-i6/3032

Rohaida, M. (2017). Tahap Pengetahuan, Pemahaman Dan Kesediaan Guru Bahasa Melayu Dalam Melaksanakan Kajian Pengajaran (Level of Knowledge, Understanding and Readiness Malay Language Teachers to Implementing Lesson Study). Jurnal Pendidikan Bahasa Melayu, 7(2), 3040. https://doi.org/10.1080/10635150600755453

Santiago, C. T. (2019). Teacher 's Affective Attitude and its Effect on their Organizational Commitment. International Journal of Sciences: Basic and Applied Research, 48(3), 78-91.

Shrotryia, V. K., \& Dhanda, U. (2019). Content Validity of Assessment Instrument for Employee Engagement. SAGE Open, 9(1), 1-7. https://doi.org/10.1177/2158244018821751

Shulman, L. S. (1987). Knowledge and Teaching: Foundations of the New Reform. Harvard Educational Review, 57(1), 1-23. https://doi.org/10.17763/haer.57.1.j463w79r56455411

Stadermann, H. K. E., \& Goedhart, M. J. (2020). Secondary school students' views of nature of science in quantum physics. International Journal of Science Education, 42(6), 997-1016. https://doi.org/10.1080/09500693.2020.1745926

Stadermann, H. K. E., Van Den Berg, E., \& Goedhart, M. J. (2019). Analysis of secondary school quantum physics curricula of 15 different countries: Different perspectives on a challenging topic. Physical Review Physics Education Research, 15(1), 1-25. https://doi.org/10.1103/PhysRevPhysEducRes.15.010130

Sumintono, B. (2016). Penilaian Keterampilan Berpikir Tingkat Tinggi : Aplikasi Pemodelan Rasch pada Asesmen Pendidikan. Seminar Nasional Pendidikan IPA, FKIP Jurusan PMIPA, Universitas Lambung Mangkurat, (September 2016), 1-19.

Sumintono, B., \& Widhiarso, W. (2015). Aplikasi Pemodelan Rasch pada Assessment Pendidikan. Cimahi: Penerbit Trim Komunikata.

Taherdoost, H. (2018). Validity and Reliability of the Research Instrument; How to Test the Validation of a Questionnaire/Survey in a Research. SSRN Electronic Journal, 5(3), 28-36. https://doi.org/10.2139/ssrn.3205040

Testa, I., Capasso, G., Colantonio, A., Galano, S., Marzoli, I., Scotti di Uccio, U., ... Zappia, A. (2019). Development and validation of a university students' progression in learning quantum mechanics through exploratory factor analysis and Rasch analysis. International Journal of Science Education, 41(3), 388-417. https://doi.org/10.1080/09500693.2018.1556414

Ulug, M., Ozden, M. S., \& Eryilmaz, A. (2011). The effects of teachers' attitudes on students' personality and performance. Procedia - Social and Behavioral Sciences, 30, 738-742. https://doi.org/10.1016/j.sbspro.2011.10.144

Ungar, O. A. (2016). Understanding teachers' attitude toward educational reforms through metaphors. International Journal of Educational Research, 77, 117-127. https://doi.org/10.1016/j.ijer.2016.03.008

Veloo, A., Krishnasamy, H. N., \& Md-Ali, R. (2015). Teachers' Knowledge and Readiness towards Implementation of School Based Assessment in Secondary Schools. International Education Studies, 8(11), 193-203. https://doi.org/10.5539/ies.v8n11p193

Wearmouth, J., Edwards, G., \& Richmond, R. (2000). Teachers' professional development to support inclusive practices. Journal of In-Service Education, 26(1), 49-61. https://doi.org/10.1080/13674580000200111

Widodo, A. (2017). Teacher Pedagogical Content Knowledge (PCK) and Students' Reasoning and Wellbeing. Journal of Physics: Conference Series, 812(012119), 1-7. https://doi.org/10.1088/1742-6596/755/1/011001

Wook Cheong, Y., \& Song, J. (2014). Different Levels of the Meaning of Wave-Particle Duality and a Suspensive Perspective on the Interpretation of Quantum Theory. Science and Education, 23(5), 1011-1030. https://doi.org/10.1007/s11191-013-9633-2

Yari, Y., Ramadany, S., Hadju, V., \& Ramba, H. La. (2019). Relationship of Knowledge, Attitude and Training with Nursing Readiness in Handling Emergency Patients in Maros District Health Center. International Journal of Science and Healthcare Research (IJSHR), 4(3), 86-92. Retrieved from www.ijshr.com

Yasin, S. N. T. M., Yunus, M. F. M., \& Ismail, I. (2018). The use of rasch measurement model for the validity and reliability. Journal of Counseling and Educational Technology, 1(2), 22. 
https://doi.org/10.32698/0111

Yusoff, M. S. B. (2019). ABC of Content Validation and Content Validity Index Calculation. Education in Medicine Journal, 11(2), 49-54. https://doi.org/10.21315/eimj2019.11.2.6

Zamanzadeh, V., Ghahramanian, A., Rassouli, M., Abbaszadeh, A., Alavi-Majd, H., \& Nikanfar, A.-R. (2015). Design and Implementation Content Validity Study: Development of an instrument for measuring Patient-Centered Communication. Journal of Caring Sciences, 4(2), 165-178. https://doi.org/10.15171/jcs.2015.017 